\title{
Metropathia hemorrhagica ovariana
}

3elo Dr. José Medina, assistente da clinica gynecologica da Faculdade de Medicina de São Paulo.

A metropathia hemorragica ovariana, embora gynecopathia perfeitamente individualisada, nem por isso parece sufficientemente comprehendida, dada a multiplicidade de denominações extravagantes que se lhe emprestam, taes como "metrorragia ovariana", "metrite chronica", "endometrite e metrite hemorragica" e endometrite hyperplastica».

Metrorragia ovariana é um sindrome em gynecologia, onde encontram guarida numerosas affecções, entre as quaes aquella de que nos occupamos. Significa apenas o symptoma que domina o scenario clinico da molestia, e nada mais. Compete á argucia clinica do especialista perscrutar-lhe a respectiva causa.

Metrite chronica, denominação criada por Skanzoni. tem-se prestado a muita confusão. Como disse Pankow deve reservar-se para aquelles uteros em que ha realmente signaes de inflamação chronica no myometrio. Os uteros metriticos, com a sua tonacidade compromettida, poderão acarretar menorragias, diz Adler, mas nunca perdas sanguineas atypicas, metrorragias. Nos uteros da metropathia não se encontram signaes de inflamação chronica (Pankow) e as perdas sanguineas subordinam-se ao typo meno-metrorragico.

Endometrite e metrite hemorragica, são denominações que não mais se justificam. Sobre falsearem a ver- 
dadeira essencia da affecção ainda consubstanciam um attentado a doutrina firmada em sciencia desde 1907, com Hitschmann e Adler, de que o factor inflammatorio em absoluto não interfere nas perturbações do cyclo menstrual, que se subordina unica e exclusivamente aos ovarios. E' um postulado que deve merecer attenção religiosa dos especialistas, já pelo seu alcance clinico, já pelo que representa de esforços e constatações admiraveis a partir de 1840, com Récamier.

Endometrite hyperplastica parece ser uma simplificação da denominação "endometrite hyperplastica ovana" proposta por Brennecke em 1882, para aquellas alterações glandulares que apresenta physiologicamente o endometrio na phase premenstrual. Brennecke muito se aproximou da realidade subordinando-as aos ovarios; o seu erro foi suppor pathologicas alterações normaes, parecendo-nos que se não errou mais, admittindo a origem bacteriana, evidentemente foi porque somente em 1885 que Schröder, na Allemanha, e Doleris, na França, contemporaneamente, se aventuraram pela primeira vez a admittir a cooparticipação dos infinitamente pequenos que vinham de ser revelados por Pasteur. Brennecke criou em 1882 aquella denominação para exprimir alterações normaes, physiologicas, premenstruaes do endometrio, e somente muito mais tarde, em 1912, é que appareceram os primeiros estudos sobre a metropathia hemorragica ovariana. Como então querer adaptal-a á um estado pathologico caracterisado pela hyperplasia glandular cystica do endometrio com a aggravante de se presuppor a origem inflammatoria dessas alterações? Como explicar-se hyperplasia inflammatoria n'uma mucosa como o endometrio, submettida a uma caducidade periodica, cada 28 dias, quando sabemos que a irritação chronica é o fundamento das hyperplasias inflammatorias? Portanto essa designação deve ser proscripta, já porque adultera o pensamento do seu criador, já porque parece subordinar a gynecopathia a um processo inflammatorio. 
Metropathia hemorragica ovariana, denomïnação proposta por Aschoff e Pankow, é a mais intelligente, synthetisando em sua propria significação a verdadeira essencia da molestia. Adoptada pelos velhos mestres da gynecologia allemã, ella concilia a natureza intrinseca da affecção com as modernas doutrinas scientificas.

A metropathia hemorragica ovariana é uma molestia que se caracterisa por perdas sanguineas mais ou menos constantes, com repercussão tão apreciavel sobre o estado geral da paciente, cuja morie pode acarretar, que Schröder chega a admittir uma acção toxica do hormone follicular sobre a medula ossea, dada a impossibilidade ás vezes de se conciliar o grau de profunda anemia da doente com as respectivas perdas sanguineas.

O exame gynecologico é em geral negativo, nada significando pequenas oscillações no volume e consistencia do utero. Os ovarios, vezes ha, mostram-se augmentados de volume, cysticos.

Pouco importa que a mulher seja ou não portadora de um processo infilammatorio que, consoante sentencia Adler, somente quando installado em plena phase catamenial, é susceptivel de alterar essa unica menstruação, tornando-a hyper-menorragica, tudo se normalisando a partir da menstruação seguinte, a menos que causas outras, por coincidencia, intercorram, perpetuando a perturbação menstrual, que não correrá nunca, será vantajoso frizar, por conta do processo inflammatorio.

E' nos ovarios que reside a verdadeira causa da molestia, numa perturbação do cyclo follicular, na persistencia dos folliculos maduros, que se não rompem, mas que se conservam. Reservatorios que são dos hormones menstruo excitadores, asseguram a persistencia das hemorragias uterinas. Ha a este respeito estudos admiraveis de Pankow e sobretudo Schröder. Porque persistem os folliculos? Mysterio.

O diagnosłico diiferencial deverá ser feilo com «aborto incompleto", "polypo mucoso", "fibroma sub mucoso» e "carcinoma do corpo do utero". 
A curettagem de prova é recurso soberano na elucidação do diagnostico. Apenas em se tratando de um fibroma sub mucoso poderá falsear a sua contribuição. No momento, empenhamo-nos em apurar se será possivel, pelas alterações da mucosa, pela direcção das glandulas e dos vasos, ou pelos signaes de atrophia da mucosa, encontrar-se senão uma orientação segura, pelo menos dados bastante aproximativos para o diagnostico differencial. E' aqui que o toque intra uterino, tão louvado por J. Adeodato, encontraria ampla justificativa.

O exame histo-pathologico, em se confirmando o diagnostico clinico, de metropathia hemorragica ovariana, deve revelar uma "hyperplasia glandular cystica do endometrio".

E' molestia peculiar á edade preclimaterica (forma senil, de Schröder), registando-se todavia por occasião do amadurecimento das funcções genitaes (forma juvenil, de Schröder).

O tratamento é variadissimo. A simples curettagem de prova, sempre imprescindivel, não raras vezes, poderá solucionar o caso. Curettagens repetidas, como aconselham alguns, serão antes prejudiciaes que uteis, em seus effeitos remotos, sobre não serem seguras em seus resultados. E' claro que uma serie de raspagens feitas com curto intervallo, attentará contra a integridade do endometrio, acarretando senão amenorrhéa pela sua remoção completa, pelo menos martyrisante dysmenorrhéa, com provavel hematometra pelas factiveis adherencias entre as paredes uterinas feridas e juxtapostas.

Tratamento muito racional é o que insinua Schröder, da «expressão dos ovarios» Mas nem sempre é applicavel, tão poucas vezes os cystos se adaptam a sua pratica.

O tratamento organotherapico é muito moroso e incertissimo em seus effeitos; cingissemo-nos a elle tão somente e a fallencia seria certa.

Um methodo, proposto por Zimmermann, facil, inocuo, que tem proporcionado resultados surprehendentes 
é o da "autohemotherapia com sangue hemolysado". A 6 cc. de agua destillada esterilisada ajuntamos 14 cc. de sangue obtido por puncção venosa, agita-se para hemolysar e injecta-se na região glutea, de 2 em 2 dias. Segundo O'Connor, Gottlieb e Freund formam-se "toxinas vasculares» durante a hemolyse, que vão excitar os centros vasos motores. Além disso o sangue hemolysado vae estimular a actividade do systema nervoso vegetativo.

Bakscht pensa que se trate de uma acção puramente proteinotherapica, insinuando a tentativa do methodo pela pela sua inocuidade e resultados inesperados. Bakscht foi além, verificando que essa autohemotherapia de sangue hemolysado somente confere resultados naquelles casos em que a "urinprobi» de Davis é positiva.

No serviço do Prof. Moraes Barros temos ensaiado o methodo com resultados animadores.

Fallida essa therapeutica corriqueira, restam dois recursos soberanos, a radiotherapia e a intervenção. A ra diumtherapia a nosso ver deve reservar-se para casos particularissimos.

Quando se decide pela radiotherapia, no Serviço do Prof. Moraes Barros, é praticada a castração unilateral, a menos que a edade da doente autorise a castração bilateral, sempre segura em seus resultados. Na forma juvenil poderá ser tentada uma "dose irritativa" sobre ambos os ovarios. A irradiação do baço, como preconisava Stefan, subsidiariamente, pode ser tentada.

Deliberada a intervenção, justificada em certo numero de casos, deixamos de abordar os methodos aconselhados, pelo caracter francamente especialisado que então assume... Adiantaremos todavia que a simples excisão fundica do utero (Beuttner), assim como a reseç̧ão ovariana, tal como preconisavam Thaler, Mansield, Köhler e Hen Kel e que Novak tentou ultimamente rehabilitar, poderão comprometter a reputação do especialista. 